\title{
Temsirolimus Sensitive Stimulation of Platelet Activity, Apoptosis and Aggregation by Collagen Related Peptide
}

\author{
Hang Cao Rosi Bissinger $^{\mathrm{a}}$ Anja T. Umbach ${ }^{\mathrm{a}}$ Meinrad Gawaz ${ }^{\mathrm{a}}$ Florian Lang ${ }^{\mathrm{b}}$
}

aDepartment of Medicine III, bDepartment of Physiology I, Eberhard-Karls-University, Tuebingen, Germany

\section{Key Words}

CRP • Platelet activation - Degranulation - Integrin • Cytosolic Ca ${ }^{2+}$ concentration • Caspase • Phosphatidylserine translocation $\bullet$ Aggregation

\begin{abstract}
Background/Aims: The mammalian target of rapamycin (mTOR) inhibitor temsirolimus stimulates apoptosis of tumor cells and is thus therapeutically used for the treatment of diverse malignancies. On the other hand, temsirolimus has been shown to protect against apoptosis of hippocampal neurons. Similar to nucleated cells, blood platelets may enter suicidal death characterized by cell shrinkage and cell membrane scrambling. Platelet apoptosis is frequently preceded by $\mathrm{Ca}^{2+}$ entry, degranulation, integrin activation and stimulation of caspases. Those events could be triggered by collagen related peptide (CRP). The present study explored whether treatment of platelets with temsirolimus modifies platelet activation, caspase activity, platelet shrinkage, and phosphatidylserine abundance. Methods: Platelets isolated from wild-type mice were exposed for 30 minutes to temsirolimus $(40 \mu \mathrm{g} / \mathrm{ml})$ without or with additional CRP $(2 \mu \mathrm{g} /$ $\mathrm{ml}$ or $5 \mu \mathrm{g} / \mathrm{ml}$ ) treatment. Flow cytometry was employed to estimate cytosolic $\mathrm{Ca}^{2+}$-activity $\left(\left[\mathrm{Ca}^{2+}\right]_{\mathrm{i}}\right)$ from Fluo-3 fluorescence, platelet degranulation from P-selectin abundance, integrin activation from $\alpha_{\text {IIb }} \beta_{3}$ integrin abundance, caspase activity utilizing an Active Caspase-3 Staining kit, phosphatidylserine abundance from annexin-V-binding and relative platelet volume from forward scatter. Results: In the absence of CRP, the administration of temsirolimus $(40 \mu \mathrm{g} / \mathrm{ml})$ significantly decreased $\left[\mathrm{Ca}^{2+}\right]_{i^{\prime}}$ but did not significantly modify P-selectin abundance, activated $\alpha_{\mathrm{mb}} \beta_{3}$ integrin, annexin-V-binding, cell volume, caspase activity and aggregation. Exposure of platelets to CRP was followed by significant increase of $\left[\mathrm{Ca}^{2+}\right]_{i^{\prime}}$ P-selectin abundance, $\alpha_{\mathrm{Ib}} \beta_{3}$ integrin activity, annexin-V-binding, ROS, caspase activity and aggregation, effects significantly blunted in the presence of temsirolimus. CRP further decreased forward scatter, an effect again significantly blunted by temsirolimus. Conclusions: Temsirolimus is a powerful inhibitor of platelet activation and suicidal platelet death.




\section{Introduction}

Temsirolimus, a selective inhibitor of the kinase mammalian target of rapamycin (mTOR) [1-9], is used for the treatment of malignancies, such as metastatic renal cell carcinoma [2, 10-37], diverse further solid tumors [38-42], refractory mantle cell lymphoma [1, 43-48], non-Hodgkin lymphomas [38, 48], and multiple myeloma [38].

Temsirolimus is effective by triggering apoptosis of tumor cells [9, 49-59] with activation of caspases [49]. On the other hand, temsirolimus has been shown to protect against apoptosis of hippocampal neurons [60] .

Side effects of temsirolimus treatment include thrombosis [61, 62], which may involve blood platelets $[63,64]$. Activation of platelets contributes to the pathogenesis of a variety of clinical disorders including arterial thrombosis, vascular inflammation and atherosclerosis [65-68] and conversely, impaired platelet function may result in bleeding disorders [69-71]. Platelets are activated by an increase of cytosolic $\mathrm{Ca}^{2+}$ concentration $\left(\left[\mathrm{Ca}^{2+}\right]_{\mathrm{i}}\right)[72]$ due to $\mathrm{Ca}^{2+}$ release from intracellular stores [73] and subsequent activation of $\mathrm{Ca}^{2+}$ release-activated channel Orai1 in the plasma membrane by the $\mathrm{Ca}^{2+}$ sensing proteins STIM1 or STIM2 [74]. Platelets could enter apoptosis, characterized by caspase activation, cell shrinkage, and cell membrane scrambling with phosphatidylserine translocation to the cell surface. Stimulators of platelet activity and apoptosis include collagen related peptide [75]. To the best of our knowledge, nothing is known about an effect of temsirolimus on platelet apoptosis.

The present study thus explored whether temsirolimus triggers or modifies platelet activation and apoptosis. In order to avoid the variability of platelet function in human individuals, experiments were performed in murine platelets.

\section{Materials and Methods}

Mice

All animal experiments were conducted according to the German law for the welfare of animals and were approved by the authorities of the state of Baden-Württemberg. Experiments were performed with blood platelets isolated from wild type mice. The mice had free access to water and control chow (Ssniff, Soest, Germany).

\section{Preparation of mouse platelets}

Platelets were obtained from 10 - to 12 -week-old mice of either sex. The mice were anesthetized and $800 \mu \mathrm{l}$ blood was drawn from the retro-orbital plexus into tubes with $200 \mu \mathrm{l}$ acid-citrate-dextrose buffer before the mice were sacrificed [76]. Platelet rich plasma (PRP) was obtained by centrifugation at $260 \mathrm{~g}$ for 5 minutes. Afterwards, PRP was centrifuged at $640 \mathrm{~g}$ for 5 minutes to pellet the platelets. Where necessary, apyrase (0.02 U/ml; Sigma-Aldrich) and prostaglandin $\mathrm{I}_{2}(0.5 \mu \mathrm{M}$; Calbiochem) were added to the PRP to prevent activation of platelets during isolation [77]. After two washing steps, the pellet of washed platelets was resuspended in modified Tyrode-HEPES buffer ( $\mathrm{pH} 7.4$, supplemented with $1 \mathrm{mM} \mathrm{CaCl}_{2}$ ). Where indicated, CRP (Roche, Basel Switzerland) was added at the indicated concentrations [78].

\section{Cytosolic calcium}

For the measurement of the cytosolic $\mathrm{Ca}^{2+}$ concentration, the platelet preparation was washed once in Tyrode buffer ( $\mathrm{pH} 7.4$ ), stained with $3 \mu \mathrm{M}$ Fluo-3AM (Biotinium, USA) in the same buffer and incubated at $37^{\circ} \mathrm{C}$ for 30 minutes. Following the indicated experimental treatment, relative fluorescence was measured utilizing a BD FACS Calibur (BD Biosciences, Heidelberg, Germany) [79].

\section{$P$-selectin and activated integrin abundance}

Fluorophore-labeled antibodies were utilized for the detection of P-selectin expression (Wug.E9FITC) and the active form of $\alpha_{\mathrm{IIb}} \beta_{3}$ integrin (JON/A-PE). Washed mouse platelets $\left(1 \times 10^{6}\right)$ were suspended in modified Tyrode buffer ( $\mathrm{pH}$ 7.4) containing $1 \mathrm{mM} \mathrm{CaCl}_{2}$ and antibodies (1:10 dilution) and subsequently 


\section{Cellular Physiology Cell Physiol Biochem 2017;42:1252-1263

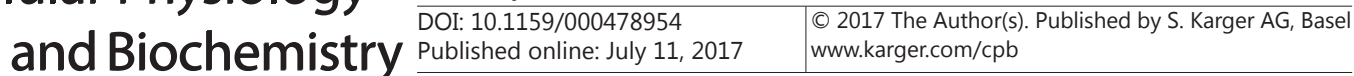 \\ Cao et al.: Temsirolimus Sensitive Platelet Function}

subjected to the respective treatments and for the indicated time periods at room temperature (RT). The reaction was stopped by addition of PBS and the samples were immediately analyzed on a BD FACSCalibur.

\section{Phosphatidylserine exposure and forward scatter}

For determination of phosphatidylserine exposure, the platelet preparation was centrifuged at $660 \mathrm{~g}$ for 5 minutes followed by washing once with Tyrode buffer (pH 7.4) with $1 \mathrm{mM} \mathrm{CaCl}_{2}$, staining with $1: 20$ dilution of Annexin-V FITC (Mabtag, Germany) in Tyrode buffer (pH 7.4) with $2 \mathrm{mM} \mathrm{CaCl}_{2}$ and incubation at $37^{\circ} \mathrm{C}$ for 30 minutes. Annexin-V binding reflecting surface exposure of phosphatidylserine was evaluated by flow cytometry utilizing a BD FACSCalibur [80]. In parallel, the forward scatter (FSC) of the platelets was determined by flow cytometry as a measure of platelet size [75].

\section{Reactive oxidant species (ROS)}

The abundance of ROS was determined utilizing 2',7'-dichlorodihydrofluorescein (DCFDA) diacetate. Washed platelets were stained with DCFDA (10 $\mu$ M; Sigma, Schnelldorf, Germany) in Tyrode buffer at $37^{\circ} \mathrm{C}$ for $30 \mathrm{~min}$ and washed once in Tyrode buffer. The DCFDA-loaded platelets were resuspended in $200 \mu \mathrm{l}$ Tyrode buffer and ROS-dependent fluorescence intensity was measured at an excitation wavelength of 488 $\mathrm{nm}$ and an emission wavelength of $530 \mathrm{~nm}$ on a BD FACS Calibur.

\section{Caspase-3 activity}

Caspase 3 activity was determined utilizing a CaspGlow Fluorescein Active Caspase-3 Staining kit from BioVision (CA, USA) according to the manufacturer's instruction. Fluorescence intensity was measured at an excitation wavelength of $488 \mathrm{~nm}$ and an emission wavelength of 530 in a BD FACSCalibur (BD Biosciences, USA).

\section{Platelet aggregation}

Aggregation was determined utilizing flow cytometry as previously described [75]. To this end, platelets were labeled with CD9-APC and CD9-PE monoclonal antibodies (1:100 dilution, Abcam) for 15 minutes at room temperature. Following incubation, differently labeled samples were washed twice, mixed $1: 1$, and then pre-incubated for $30 \mathrm{~min}$ at $37^{\circ} \mathrm{C}$ while shaking at $600 \mathrm{rpm}$ for 10 minutes. Pre-incubated platelets were activated with $2 \mu \mathrm{g} / \mathrm{ml} \mathrm{CRP}$ at $37^{\circ} \mathrm{C}$ while shaking at $1000 \mathrm{rpm}$. At the indicated time points, samples were fixed by addition of $0.5 \%$ paraformaldehyde (Carl Roth, Germany) in phosphate-buffered saline. The fixed samples were measured utilizing a BD FACSCalibur (BD Biosciences, Heidelberg, Germany). For quantification, a quadrant was set in the dot plot of respective channels on non-stimulated platelets. The appearance of double-colored events in the upper right quadrant (Q2) was quantified as percentage of total amount of labeled events $(\mathrm{Q} 1+\mathrm{Q} 2+\mathrm{Q} 4)$ at every time point analyzed.

\section{Statistical analysis}

Data are provided as means \pm SEM; $n$ represents the number of independent experiments. All data were tested for significance using ANOVA with Tukey's test as post-test or unpaired student's t-test as appropriate. Results with $p<0.05$ were considered statistically significant.

\section{Results}

The present study explored whether temsirolimus modifies platelet activity and apoptosis without and with additional stimulation by collagen related peptide (CRP). Murine platelets were isolated from wild type mice and exposed to CRP $(2 \mu \mathrm{g} / \mathrm{ml}$ or $5 \mu \mathrm{g} /$ $\mathrm{ml}$ ) without and with presence of temsirolimus ( $40 \mu \mathrm{g} / \mathrm{ml}, 30$ minutes).

Fluo-3 fluorescence, determined by flow cytometry, was employed to estimate cytosolic $\mathrm{Ca}^{2+}$ concentration $\left(\left[\mathrm{Ca}^{2+}\right]_{\mathrm{i}}\right)$. Without presence of CRP, platelet $\left[\mathrm{Ca}^{2+}\right]_{\mathrm{i}}$ was slightly, but significantly decreased by addition of temsirolimus (Fig. 1). Treatment with CRP was followed by a marked significant increase of $\left[\mathrm{Ca}^{2+}\right]_{i}$, an effect significantly blunted in the presence of temsirolimus (Fig. 1).

The abundance of reactive oxygen species (ROS) was quantified utilizing DCFDA fluorescence. In the absence of CRP, treatment with temsirolimus was followed by a significant 


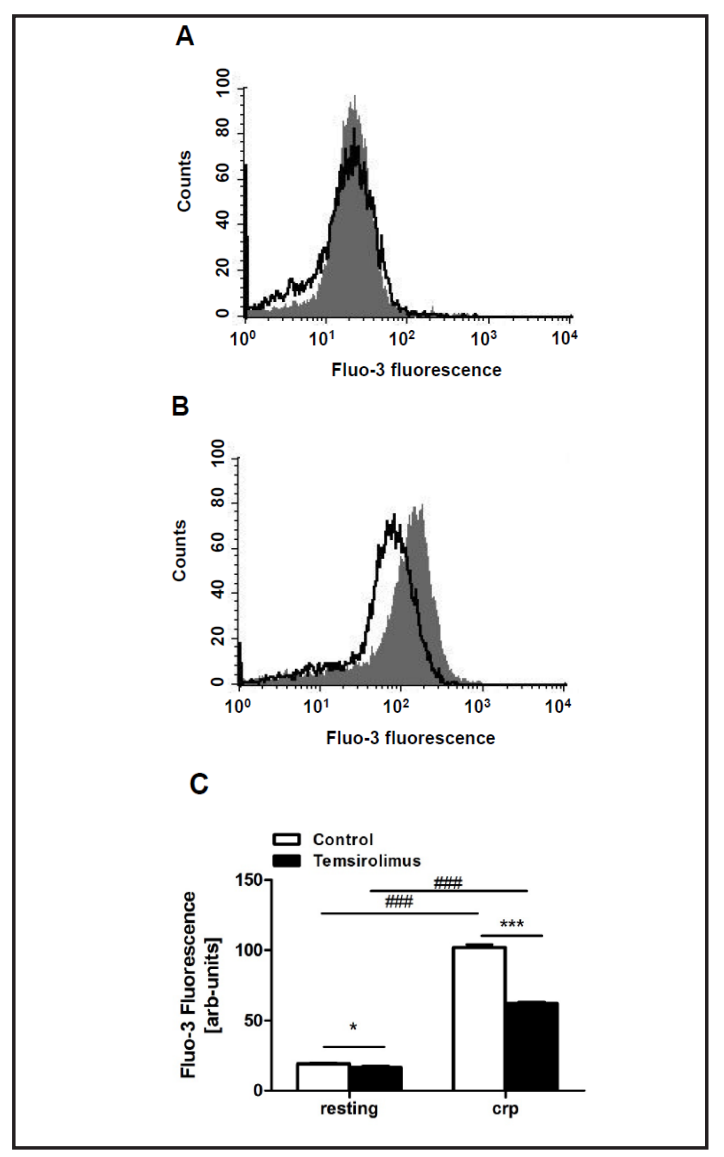

Fig. 1. Temsirolimus sensitive CRP-induced increase of cytosolic $\mathrm{Ca}^{2+}$ concentration. A,B. Original histogram overlays of Fluo-3 fluorescence reflecting cytosolic $\mathrm{Ca}^{2+}$ activity in murine platelets without (A) and with (B) a $150 \mathrm{~s}$ treatment with CRP $(2 \mu \mathrm{g} / \mathrm{ml})$ without (grey areas) and with (black lines) presence of temsirolimus ( $40 \mu \mathrm{g} / \mathrm{ml}, 30$ minutes). C. Arithmetic means \pm SEM $(n=6)$ of Fluo-3 fluorescence reflecting cytosolic $\mathrm{Ca}^{2+}$ activity in murine platelets without (left bars) and with (right bars) a $150 \mathrm{~s}$ CRP treatment $(2 \mu \mathrm{g} / \mathrm{ml})$ in the absence (white bars) and presence (black bars) of $40 \mu \mathrm{g} / \mathrm{ml}$ temsirolimus. \#\#\# $(\mathrm{p}<0.001)$ indicates statistically significant difference from absence of CRP, * $(\mathrm{p}<0.05)$, *** $(p<0.001)$ indicates statistically significant difference from absence of temsirolimus.

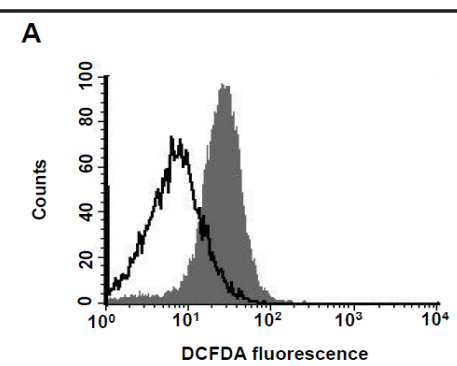

B

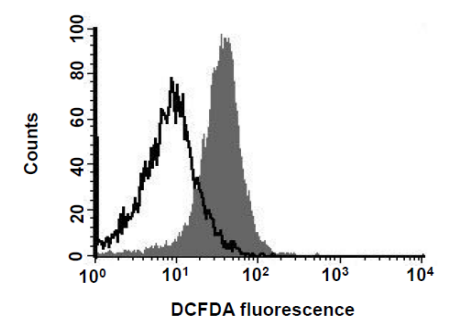

C

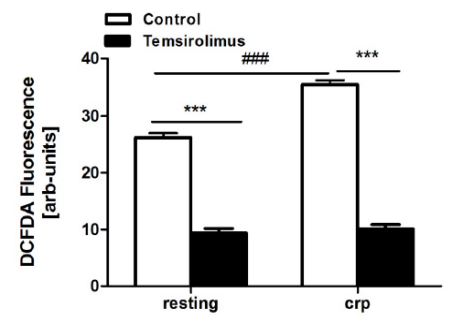

Fig. 2. Temsirolimus and CRP sensitive reactive oxygen species. A,B. Original histogram overlays of DCFDA fluorescence reflecting ROS abundance (arbitrary units) in murine platelets without (A) and with a 10 min treatment with (B) CRP $(2 \mu \mathrm{g} / \mathrm{ml})$ without (grey areas) and with (black lines) presence of temsirolimus $(40 \mu \mathrm{g} / \mathrm{ml}, 30 \mathrm{~min})$. C. Arithmetic means \pm SEM ( $n=4$ ) of DCFDA fluorescence reflecting ROS abundance (arbitrary units) in murine platelets in the absence (white bars) and presence (black bars) of 40 $\mu \mathrm{g} / \mathrm{ml}$ temsirolimus without (resting) and with a 10 min CRP $(2 \mu \mathrm{g} / \mathrm{ml})$ treatment. \#\#\# $(\mathrm{p}<0.001)$ indicates statistically significant difference from absence of CRP, *** $(\mathrm{p}<0.001)$ indicates statistically significant difference from absence of temsirolimus.

decrease of the ROS abundance (Fig. 2). The ROS abundance was significantly enhanced by treatment of the platelets with CRP. Temsirolimus virtually abrogated the effect of CRP on the ROS abundance (Fig. 2).

Increase of P-selectin abundance at the platelet surface, determined by flow cytometry utilizing specific antibodies, was taken as evidence for platelet degranulation. As illustrated in Fig. 3, without presence of CRP, the P-selectin abundance at the platelet surface was negligible in both, absence and presence of temsirolimus. CRP treatment markedly and significantly increased P-selectin abundance, an effect significantly blunted in the presence of temsirolimus (Fig. 3). 


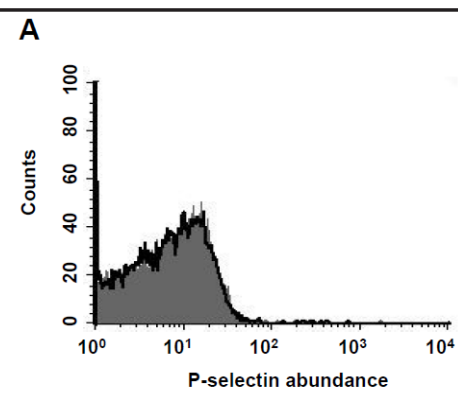

B

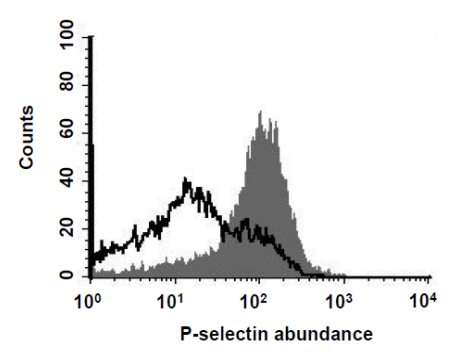

C

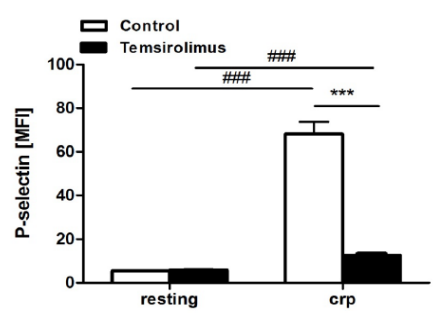

Fig. 3. Temsirolimus sensitive CRP-induced platelet degranulation. A,B. Original histogram overlays of P-selectin related fluorescence in murine platelets without (A) and with (B) a 15 minutes CRP (2 $\mu \mathrm{g} /$ $\mathrm{ml}$ ) treatment without (grey areas) and with (black lines) presence of temsirolimus $(40 \mu \mathrm{g} / \mathrm{ml}, 30 \mathrm{mi}-$ nutes). C. Arithmetic means \pm SEM $(n=6)$ of the P-selectin related fluorescence (arbitrary units) in murine platelets without (left bars) and with (right bars) a 15 minutes CRP treatment $(2 \mu \mathrm{g} / \mathrm{ml})$ in the absence (white bars) and presence (black bars) of $40 \mu \mathrm{g} / \mathrm{ml}$ temsirolimus. \#\#\# $(\mathrm{p}<0.001)$ indicates statistically significant difference from absence of CRP, *** $(\mathrm{p}<0.001)$ indicates statistically significant difference from absence of temsirolimus.

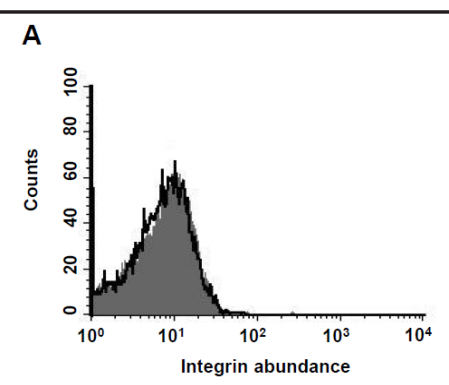

B

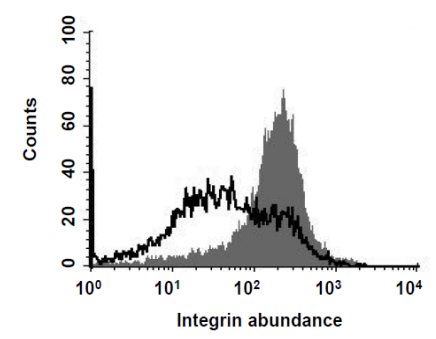

C

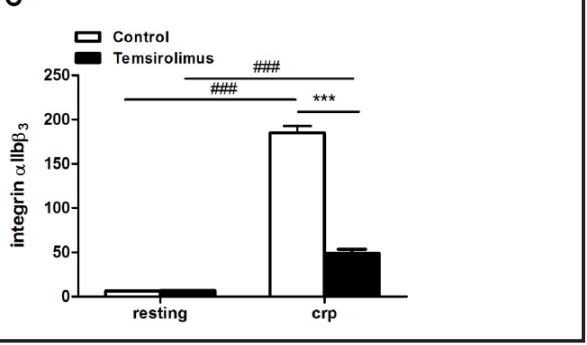

Fig. 4. Temsirolimus sensitive CRP-induced $\alpha_{\mathrm{IIb}} \beta_{3}$ integrin activation. A,B. Original histogram overlays of active $\alpha_{\mathrm{IIb}} \beta_{3}$ integrin related fluorescence in murine platelets without (A) and with (B) a 15 minutes CRP $(2 \mu \mathrm{g} / \mathrm{ml})$ treatment without (grey areas) and with (black lines) presence of temsirolimus $(40 \mu \mathrm{g} / \mathrm{ml}, 30$ minutes). C. Arithmetic means $\pm \operatorname{SEM}(\mathrm{n}=6)$ of the $\alpha_{\mathrm{I}}$ ${ }_{\mathrm{Ib}} \beta_{3}$ integrin related fluorescence (arbitrary units) in murine platelets without (left bars) and with (right bars) a 15 minutes CRP treatment $(2 \mu \mathrm{g} / \mathrm{ml})$ in the absence (white bars) and presence (black bars) of 40 $\mu \mathrm{g} / \mathrm{ml}$ temsirolimus. \#\#\# $(\mathrm{p}<0.001)$ indicates statistically significant difference from absence of CRP, $* * *(\mathrm{p}<0.001)$ indicates statistically significant difference from absence of temsirolimus.

The abundance of active integrin $\alpha_{\mathrm{IIb}} \beta_{3^{3}}$, determined by flow cytometry utilizing specific antibodies, was again negligible in the absence of CRP irrespective of the absence or presence of temsirolimus (Fig. 4). The abundance of active integrin $\alpha_{\mathrm{II}} \beta_{3}$ was markedly and significantly increased by CRP treatment, an effect again significantly blunted by temsirolimus (Fig. 4).

A kit has been used for the detection of activated caspase 3. As illustrated in Fig. 5, without presence of CRP, caspase activity was negligible in both, absence and presence of temsirolimus. CRP significantly increased the caspase activity, an effect significantly blunted by temsirolimus treatment (Fig. 5).

Phosphatidylserine abundance was estimated from annexin-V-binding. As shown in Fig. 6, the percentage of annexin- $\mathrm{V}$ positive platelets was negligible in the absence of CRP irrespective 


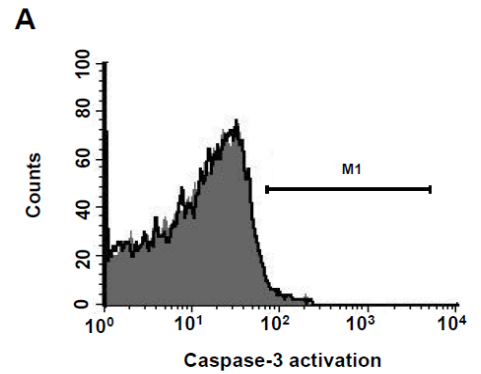

B

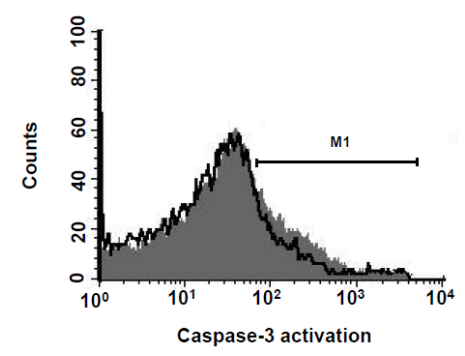

C

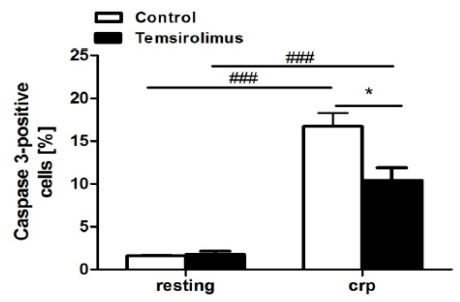

Fig. 5. Temsirolimus sensitive CRP-dependent caspase activation. A,B. Original histogram overlays of fluorescence reflecting caspase- 3 activity in murine platelets without (A) and with (B) a 10 minutes CRP $(5 \mu \mathrm{g} / \mathrm{ml})$ treatment without (grey areas) and with (black lines) presence of temsirolimus $(40 \mu \mathrm{g} / \mathrm{ml}$, 30 minutes). C. Arithmetic means \pm SEM $(n=4)$ of fluorescence reflecting caspase- 3 activity in murine platelets without (left bars) and with (right bars) a 10 minutes CRP treatment $(5 \mu \mathrm{g} / \mathrm{ml})$ in the absence (white bars) and presence (black bars) of $40 \mu \mathrm{g} /$ $\mathrm{ml}$ temsirolimus. \#\#\# $(\mathrm{p}<0.001)$ indicates statistically significant difference from absence of CRP, * $(p<0.05)$ indicates statistically significant difference from absence of temsirolimus.

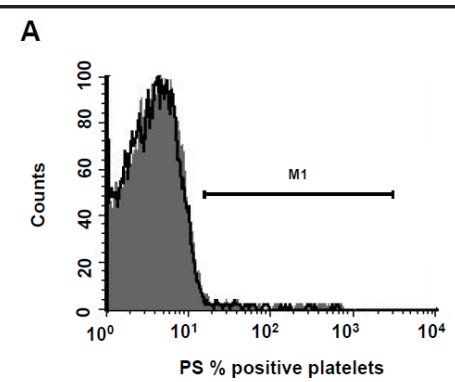

8
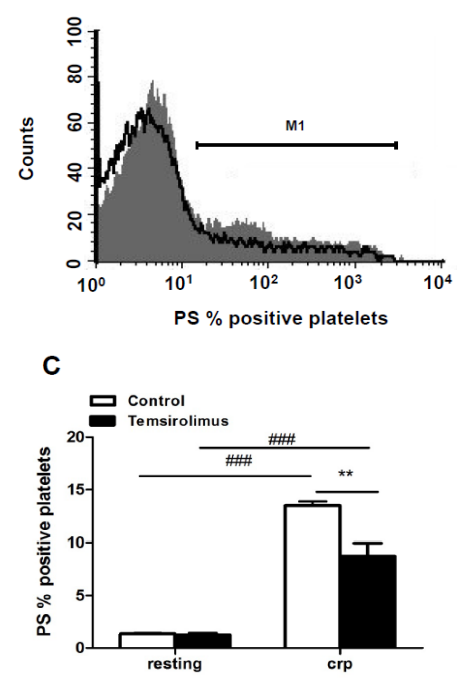

Fig. 6. Temsirolimus sensitive CRP-dependent cell membrane scrambling. A,B. Original histogram overlays of annexin-V-binding reflecting phosphatidylserine abundance at the surface of murine platelets without (A) and with (B) a 10 minutes CRP $(5 \mu \mathrm{g} / \mathrm{ml})$ treatment without (grey areas) and with (black lines) presence of temsirolimus ( $40 \mu \mathrm{g} / \mathrm{ml}, 30$ minutes). C. Arithmetic means \pm SEM $(n=6)$ of annexin-V-binding reflecting phosphatidylserine abundance at the surface of murine platelets without (left bars) and with (right bars) a 10 minutes CRP treatment ( $5 \mu \mathrm{g} /$ $\mathrm{ml}$ ) in the absence (white bars) and presence (black bars) of $40 \mu \mathrm{g} / \mathrm{ml}$ temsirolimus. \#\#\# ( $<<0.001)$ indicates statistically significant difference from absence of CRP, ${ }^{* *}(\mathrm{p}<0.01)$ indicates statistically significant difference from absence of temsirolimus.

of the absence or presence of temsirolimus. CRP treatment markedly and significantly enhanced the percentage of annexin- $\mathrm{V}$ binding platelets, an effect again significantly blunted in the presence of temsirolimus (Fig. 6).

Platelet volume was estimated from forward scatter, which was determined by flow cytometry. As illustrated in Fig. 7, in the absence of CRP, the forward scatter was similar in the absence and presence of temsirolimus. CRP treatment markedly and significantly decreased forward scatter, an effect again significantly blunted in the presence of temsirolimus (Fig. 7).

To elucidate the effect of temsirolimus on platelet aggregation, platelets were labeled with two distinct dyes and the coincidence of the two dyes estimated by flow cytometry. As illustrated 


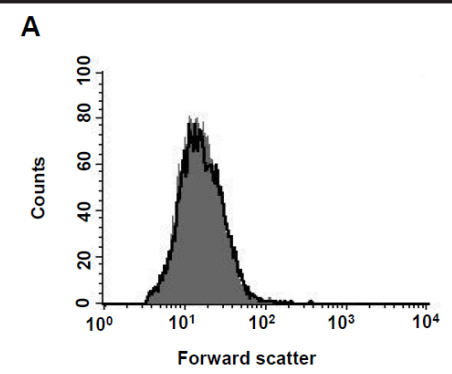

B

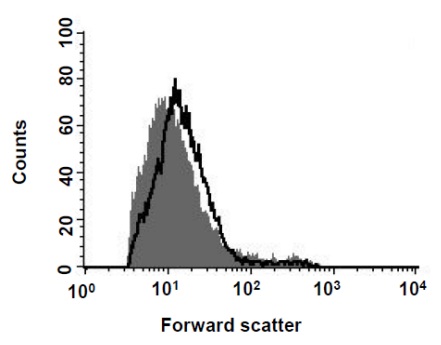

C

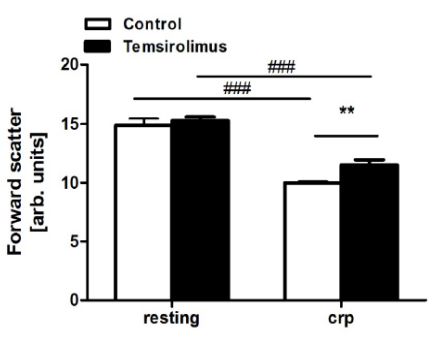

Fig. 7. Temsirolimus sensitive CRP-dependent cell shrinkage. A,B. Original histogram overlays of forward scatter reflecting cell volume of murine platelets without (A) and with (B) a 10 minutes CRP $(5 \mu \mathrm{g} / \mathrm{ml})$ treatment without (grey areas) and with (black lines) presence of temsirolimus $(40 \mu \mathrm{g} / \mathrm{ml}$, 30 minutes). C. Arithmetic means $\pm \operatorname{SEM}(n=6)$ of forward scatter reflecting cell volume of murine platelets without (left bars) and with (right bars) a 10 minutes CRP treatment $(5 \mu \mathrm{g} / \mathrm{ml})$ in the absence (white bars) and presence (black bars) of $40 \mu \mathrm{g} /$ ml temsirolimus. \#\#\# ( $<<0.001)$ indicates statistically significant difference from absence of CRP, ** $(p<0.01)$ indicates statistically significant difference from absence of temsirolimus.

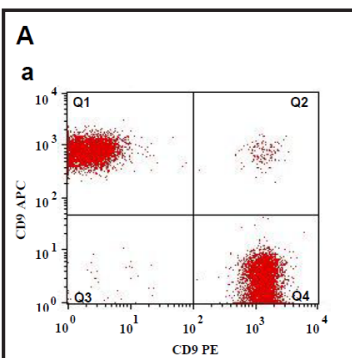

c
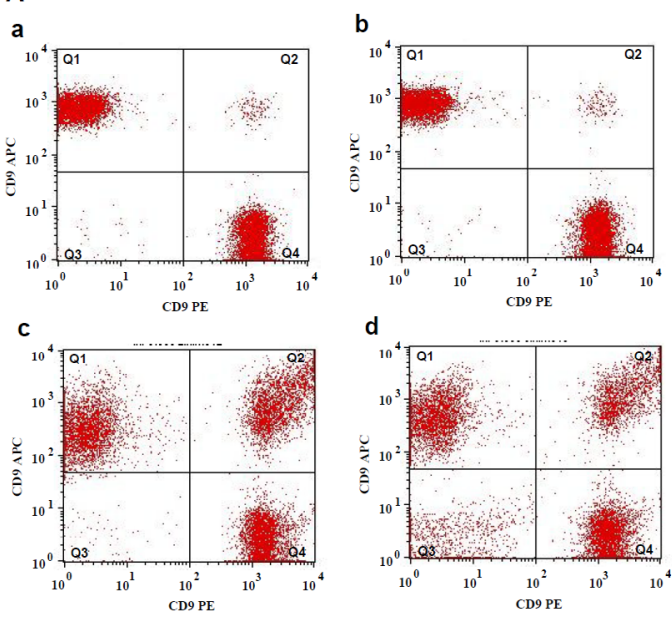

d

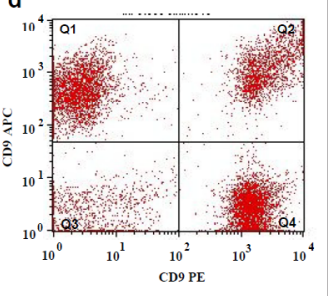

B

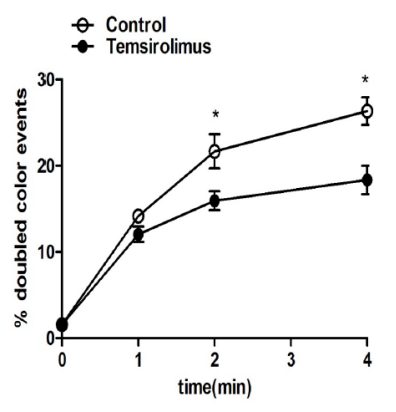

Fig. 8. Temsirolimus sensitive CRP-dependent platelet aggregation. A. Original dot blots reflecting platelet aggregation without $(a, b)$ and with (c, d) 4 min treatment with CRP $(2 \mu \mathrm{g} / \mathrm{ml})$ in the absence (a, c) and presence (b, d) of $40 \mu \mathrm{g} / \mathrm{ml}$ temsirolimus. B. Arithmetic means \pm SEM ( $n=4)$ of platelet aggregation without (white circles) and with (black circles) prior $40 \mu \mathrm{g} / \mathrm{ml}$ temsirolimus treatment as a function of time after addition of CRP $(2 \mu \mathrm{g} / \mathrm{ml}) *(\mathrm{p}<0.05)$ indicates statistically significant difference between absence and presence of temsirolimus.

in Fig. 8, aggregation was markedly and significantly enhanced by treatment of the platelets with CRP. Temsirolimus significantly blunted the effect of CRP on the aggregation (Fig. 8).

\section{Discussion}

The present observations reveal a novel effect of temsirolimus, i.e. its effect on platelet function and survival. Temsirolimus significantly decreases cytosolic $\mathrm{Ca}^{2+}$ activity $\left(\left[\mathrm{Ca}^{2+}\right]_{\mathrm{i}}\right)$ and the abundance of reactive oxygen species (ROS) and significantly blunts or virtually abrogates the effect of collagen related peptide (CRP) on $\left[\mathrm{Ca}^{2+}\right]_{i}, \mathrm{ROS}$, degranulation, 


\section{Cellular Physiology Cell Physiol Biochem 2017;42:1252-1263

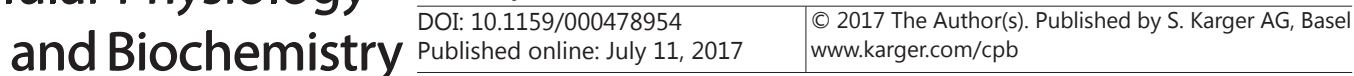 \\ Cao et al.: Temsirolimus Sensitive Platelet Function}

$\alpha_{\mathrm{IIb}} \beta_{3}$ integrin activity, caspase 3 activity, cell membrane scrambling, cell volume, and aggregation.

Platelet activation and apoptosis are a function of cytosolic $\mathrm{Ca}^{2+}$ activity $\left(\left[\mathrm{Ca}^{2+}\right]_{\mathrm{i}}\right), \mathrm{a}$ powerful regulator of platelet activation involved in the pathophysiology of arterial thrombosis [72]. An increase of $\left[\mathrm{Ca}^{2+}\right]_{i}$ further stimulates breakdown of the phosphatidylserine asymmetry of the cell membrane with translocation of phosphatidylserine to the platelet surface. Phosphatidylserine at the platelet surface fosters coagulation and is thus a decisive stimulator of hemostasis [81]. Phosphatidylserine exposing platelets are further bound to and engulfed by macrophages [82]. In view of the present observations, temsirolimus may counteract platelet activation, hemostasis and thrombosis. It is tempting to propose the use of temsirolimus for the treatment of conditions with enhanced platelet reagibility, such as arterial thrombosis, vascular inflammation and atherosclerosis [65-68]. On the other hand, the present observations advocate caution when using temsiroliums in clinical conditions associated with impaired platelet function, such as hepatic failure [70]. However, additional experimental effort particularly in vivo is required to fully define the effect of temsirolimus in the physiology and pathophysiology of platelets.

In conclusion, temsirolimus blunts the CRP-induced increase of $\left[\mathrm{Ca}^{2+}\right]_{\mathrm{i}}$, ROS, P-selectin abundance, $\alpha_{\mathrm{IIb}} \beta_{3}$ integrin activity, caspase activity, annexin-V-binding, cell volume and aggregation, and may thus counteract platelet activation and apoptosis.

\section{Acknowledgements}

We thank Efi Faber for providing technical assistance as well as Lejla Subasic for meticulous preparation of the manuscript. This study was supported by the Deutsche Forschungsgemeinschaft and Open Access Publishing Fund of Tuebingen University - Klinische Forschergruppe [DFG-KFO 274] 'Platelets-Molecular Mechanisms and Translational Implications', as well as the Tuebingen Platelet Investigative Consortium (TuePIC). Work of R.B. is supported by the Institutional Strategy of the University of Tübingen (Deutsche Forschungsgemeinschaft, ZUK63).

\section{Disclosure Statement}

The authors of this manuscript state that they have no conflicts of interest to declare.

\section{References}

-1 Schulze M, Stock C, Zaccagnini M, Teber D, Rassweiler JJ: Temsirolimus. Recent Results Cancer Res 2014;201:393-403.

-2 Bukowski RM: Temsirolimus: a safety and efficacy review. Expert Opin Drug Saf 2012;11:861-879.

3 Peuvrel L, Quereux G, Brocard A, Saint-Jean M, Dreno B: Onychopathy induced by temsirolimus, a mammalian target of rapamycin inhibitor. Dermatology 2012;224:204-208.

4 Gomez-Fernandez C, Garden BC, Wu S, Feldman DR, Lacouture ME: The risk of skin rash and stomatitis with the mammalian target of rapamycin inhibitor temsirolimus: a systematic review of the literature and meta-analysis. Eur J Cancer 2012;48:340-346.

5 De Masson A, Fouchard N, Mery-Bossard L, Dauendorffer JN: Cutaneous and mucosal aphthosis during temsirolimus therapy for advanced renal cell carcinoma: review of cutaneous and mucosal side effects of mTOR inhibitors. Dermatology 2011;223:4-8.

-6 Stock C, Zaccagnini M, Schulze M, Teber D, Rassweiler JJ: Temsirolimus. Recent Results Cancer Res 2010;184:189-197. 


\section{Cellular Physiology Cell Physiol Biochem 2017;42:1252-1263 \begin{tabular}{l|l} 
DOI: 10.1159/000478954 2017 & $\begin{array}{l}\text { O 2017 The Author(s). Published by S. Karger AG, Basel } \\
\text { www.karger.com/cpb }\end{array}$ \\
\cline { 2 - 3 }
\end{tabular} \\ Cao et al.: Temsirolimus Sensitive Platelet Function}

7 Boni JP, Hug B, Leister C, Sonnichsen D: Intravenous temsirolimus in cancer patients: clinical pharmacology and dosing considerations. Semin Oncol 2009;36 Suppl 3:S18-25.

8 Rini BI: Temsirolimus, an inhibitor of mammalian target of rapamycin. Clin Cancer Res 2008;14:12861290.

9 Ma WW, Jimeno A: Temsirolimus. Drugs Today (Barc) 2007;43:659-669.

10 Porta C, Tortora G, Larkin JM, Hutson TE: Management of poor-risk metastatic renal cell carcinoma: current approaches, the role of temsirolimus and future directions. Future Oncol 2016;12:533-549.

11 Zanardi E, Verzoni E, Grassi P, Necchi A, Giannatempo P, Raggi D, De Braud F, Procopio G: Clinical experience with temsirolimus in the treatment of advanced renal cell carcinoma. Ther Adv Urol 2015;7:152-161.

-12 Afshar M, Pascoe J, Whitmarsh S, James N, Porfiri E: Temsirolimus for patients with metastatic renal cell carcinoma: outcomes in patients receiving temsirolimus within a compassionate use program in a tertiary referral center. Drug Des Devel Ther 2015;9:13-19.

13 Iacovelli R, Santoni M, Verzoni E, Grassi P, Testa I, de Braud F, Cascinu S, Procopio G: Everolimus and temsirolimus are not the same second-line in metastatic renal cell carcinoma. A systematic review and meta-analysis of literature data. Clin Genitourin Cancer 2015;13:137-141.

14 Hutson TE, Escudier B, Esteban E, Bjarnason GA, Lim HY, Pittman KB, Senico P, Niethammer A, Lu DR, Hariharan S, Motzer RJ: Randomized phase III trial of temsirolimus versus sorafenib as second-line therapy after sunitinib in patients with metastatic renal cell carcinoma. J Clin Oncol 2014;32:760-767.

15 Payton S: Kidney cancer: Temsirolimus fails to expand its role in patients with mRCC. Nat Rev Urol 2014;11:2.

16 Wong MK, Yang H, Signorovitch JE, Wang X, Liu Z, Liu NS, Qi CZ, George DJ: Comparative outcomes of everolimus, temsirolimus and sorafenib as second targeted therapies for metastatic renal cell carcinoma: a US medical record review. Curr Med Res Opin 2014;30:537-545.

17 Schrader AJ, Seseke S, Keil C, Herrmann E, Goebell PJ, Weikert S, Steffens S, Bergmann L, Roigas J, Steiner T: Temsirolimus in daily use: results of a prospective multicentre noninterventional study of patients with metastatic kidney cancer. Eur Urol 2014;66:275-281.

-18 Stenner-Liewen F, Grunwald V, Greil R, Porta C: The clinical potential of temsirolimus in second or later lines of treatment for metastatic renal cell carcinoma. Expert Rev Anticancer Ther 2013;13:1021-1033.

19 Venugopal B, Ansari J, Aitchison M, Tho LM, Campbell R, Jones RJ: Efficacy of temsirolimus in metastatic chromophobe renal cell carcinoma. BMC Urol 2013;13:26.

20 Hadoux J, Vignot S, De La Motte Rouge T: Renal cell carcinoma: focus on safety and efficacy of temsirolimus. Clin Med Insights Oncol 2010;4:143-154.

21 Maroto JP, Hudes G, Dutcher JP, Logan TF, White CS, Krygowski M, Cincotta M, Shapiro M, Duran I, Berkenblit A: Drug-related pneumonitis in patients with advanced renal cell carcinoma treated with temsirolimus. J Clin Oncol 2011;29:1750-1756.

-22 Gerullis H, Ecke TH, Eimer C, Heuck CJ, Otto T: mTOR-inhibition in metastatic renal cell carcinoma. Focus on temsirolimus: a review. Minerva Urol Nefrol 2010;62:411-423.

-23 Mackenzie MJ, Rini BI, Elson P, Schwandt A, Wood L, Trinkhaus M, Bjarnason G, Knox J: Temsirolimus in VEGF-refractory metastatic renal cell carcinoma. Ann Oncol 2011;22:145-148.

-24 Kwitkowski VE, Prowell TM, Ibrahim A, Farrell AT, Justice R, Mitchell SS, Sridhara R, Pazdur R: FDA approval summary: temsirolimus as treatment for advanced renal cell carcinoma. Oncologist 2010;15:428435.

25 Norum J, Nieder C, Kondo M: Sunitinib, sorafenib, temsirolimus or bevacizumab in the treatment of metastatic renal cell carcinoma: a review of health economic evaluations. J Chemother 2010;22:75-82.

26 Ravaud A, Bernhard JC, Gross-Goupil M, Digue L, Ferriere JM: [mTOR inhibitors: temsirolimus and everolimus in the treatment of renal cell carcinoma]. Bull Cancer 2010;97:45-51.

27 Guevremont C, Alasker A, Karakiewicz PI: Management of sorafenib, sunitinib, and temsirolimus toxicity in metastatic renal cell carcinoma. Curr Opin Support Palliat Care 2009;3:170-179.

28 Hudes GR, Berkenblit A, Feingold J, Atkins MB, Rini BI, Dutcher J: Clinical trial experience with temsirolimus in patients with advanced renal cell carcinoma. Semin Oncol 2009;36 Suppl 3:S26-36.

29 Thompson Coon J, Hoyle M, Green C, Liu Z, Welch K, Moxham T, Stein K: Bevacizumab, sorafenib tosylate, sunitinib and temsirolimus for renal cell carcinoma: a systematic review and economic evaluation. Health Technol Assess 2010;14:1-184, iii-iv. 


\section{Cellular Physiology Cell Physiol Biochem 2017;42:1252-1263 \begin{tabular}{l|l} 
DOI: 10.1159/000478954, 2017 & $\begin{array}{l}\text { O 2017 The Author(s). Published by S. Karger AG, Basel } \\
\text { www.karger.com/cpb }\end{array}$ \\
\cline { 2 - 3 }
\end{tabular} \\ Cao et al.: Temsirolimus Sensitive Platelet Function}

30 Bhatia S, Thompson JA: Temsirolimus in patients with advanced renal cell carcinoma: an overview. Adv Ther 2009;26:55-67.

31 Parikh J, Coleman T, Messias N, Brown J: Temsirolimus in the treatment of renal cell carcinoma associated with Xp11.2 translocation/TFE gene fusion proteins: a case report and review of literature. Rare Tumors 2009;1:e53.

-32 Le Tourneau C, Faivre S, Serova M, Raymond E: mTORC1 inhibitors: is temsirolimus in renal cancer telling us how they really work? Br J Cancer 2008;99:1197-1203.

33 Malizzia LJ, Hsu A: Temsirolimus, an mTOR inhibitor for treatment of patients with advanced renal cell carcinoma. Clin J Oncol Nurs 2008;12:639-646.

-34 Figlin RA: Mechanisms of Disease: survival benefit of temsirolimus validates a role for mTOR in the management of advanced RCC. Nat Clin Pract Oncol 2008;5:601-609.

-35 Simpson D, Curran MP: Temsirolimus: in advanced renal cell carcinoma. Drugs 2008;68:631-638.

-36 Bhojani N, Jeldres C, Patard JJ, Perrotte P, Suardi N, Hutterer G, Patenaude F, Oudard S, Karakiewicz PI: Toxicities associated with the administration of sorafenib, sunitinib, and temsirolimus and their management in patients with metastatic renal cell carcinoma. Eur Urol 2008;53:917-930.

37 Gore ME: Temsirolimus in the treatment of advanced renal cell carcinoma. Ann Oncol 2007;18 Suppl 9:ix87-88.

38 Dancey JE, Curiel R, Purvis J: Evaluating temsirolimus activity in multiple tumors: a review of clinical trials. Semin Oncol 2009;36 Suppl 3:S46-58.

-39 Abdel-Rahman 0, Fouad M: Risk of oral and gastrointestinal mucosal injury in patients with solid tumors treated with everolimus, temsirolimus or ridaforolimus: a comparative systematic review and metaanalysis. Expert Rev Anticancer Ther 2015;15:847-858.

40 Bagatell R, Norris R, Ingle AM, Ahern C, Voss S, Fox E, Little AR, Weigel BJ, Adamson PC, Blaney S: Phase 1 trial of temsirolimus in combination with irinotecan and temozolomide in children, adolescents and young adults with relapsed or refractory solid tumors: a Children's Oncology Group Study. Pediatr Blood Cancer 2014;61:833-839.

41 Xu J, Tian D: Hematologic toxicities associated with mTOR inhibitors temsirolimus and everolimus in cancer patients: a systematic review and meta-analysis. Curr Med Res Opin 2014;30:67-74.

42 Geoerger B, Kieran MW, Grupp S, Perek D, Clancy J, Krygowski M, Ananthakrishnan R, Boni JP, Berkenblit A, Spunt SL: Phase II trial of temsirolimus in children with high-grade glioma, neuroblastoma and rhabdomyosarcoma. Eur J Cancer 2012;48:253-262.

43 Dreyling M, Jurczak W, Jerkeman M, Silva RS, Rusconi C, Trneny M, Offner F, Caballero D, Joao C, WitzensHarig M, Hess G, Bence-Bruckler I, Cho SG, Bothos J, Goldberg JD, Enny C, Traina S, Balasubramanian S, Bandyopadhyay N, Sun S, Vermeulen J, Rizo A, Rule S: Ibrutinib versus temsirolimus in patients with relapsed or refractory mantle-cell lymphoma: an international, randomised, open-label, phase 3 study. Lancet 2016;387:770-778.

44 Coiffier B: Clinical efficacy and management of temsirolimus in patients with relapsed or refractory mantle cell lymphoma. Clin Lymphoma Myeloma Leuk 2013;13:351-359.

45 Bouabdallah K, Ribrag V, Terriou L, Soria JC, Delarue R: Temsirolimus in the treatment of mantle cell lymphoma: frequency and management of adverse effects. Curr Opin Oncol 2013;25 Suppl 2:S1-12.

-46 Hess G: Temsirolimus for the treatment of mantle cell lymphoma. Expert Rev Hematol 2009;2:631-640.

-47 Hoy SM, McKeage K: Temsirolimus: In relapsed and/or refractory mantle cell lymphoma. Drugs 2010;70:1819-1829.

48 Hess G, Smith SM, Berkenblit A, Coiffier B: Temsirolimus in mantle cell lymphoma and other non-Hodgkin lymphoma subtypes. Semin Oncol 2009;36 Suppl 3:S37-45.

49 Kang HG, Wang BZ, Zhang J, Liu MR, Li YX: Combination of temsirolimus and adriamycin exhibits an enhanced antitumor effect in hepatocellular carcinoma. Clin Res Hepatol Gastroenterol 2017;41:197-203.

50 Vazakidou ME, Magkouta S, Moschos C, Psallidas I, Pappas A, Psarra K, Kalomenidis I: Temsirolimus targets multiple hallmarks of cancer to impede mesothelioma growth in vivo. Respirology 2015;20:1263-1271.

51 Zoellner AK, Weiglein T, Hutter G, Zimmermann Y, Cieplik HC, Hess G, Dreyling M: Temsirolimus acts as additive with bendamustine in aggressive lymphoma. Ann Hematol 2016;95:403-407.

52 Carew JS, Espitia CM, Zhao W, Mita MM, Mita AC, Nawrocki ST: Targeting Survivin Inhibits Renal Cell Carcinoma Progression and Enhances the Activity of Temsirolimus. Mol Cancer Ther 2015;14:1404-1413. 


\section{Cellular Physiology Cell Physiol Biochem 2017;42:1252-1263 \begin{tabular}{l|l} 
DOI: 10.1159/000478954 2017 & $\begin{array}{l}\text { O 2017 The Author(s). Published by S. Karger AG, Basel } \\
\text { www.karger.com/cpb }\end{array}$ \\
\hline
\end{tabular}

-53 Fleuren ED, Versleijen-Jonkers YM, Roeffen MH, Franssen GM, Flucke UE, Houghton PJ, Oyen WJ, Boerman OC, van der Graaf WT: Temsirolimus combined with cisplatin or bevacizumab is active in osteosarcoma models. Int J Cancer 2014;135:2770-2782.

54 Kaneko M, Nozawa H, Hiyoshi M, Tada N, Murono K, Nirei T, Emoto S, Kishikawa J, Iida Y, Sunami E, Tsuno NH, Kitayama J, Takahashi K, Watanabe T: Temsirolimus and chloroquine cooperatively exhibit a potent antitumor effect against colorectal cancer cells. J Cancer Res Clin Oncol 2014;140:769-781.

55 Pinto-Leite R, Arantes-Rodrigues R, Ferreira R, Palmeira C, Colaco A, Moreira da Silva V, Oliveira P, Lara Santos L: Temsirolimus improves cytotoxic efficacy of cisplatin and gemcitabine against urinary bladder cancer cell lines. Urol Oncol 2014;32:41.e11-22.

-56 Sperling J, Ziemann C, Gittler A, Benz-Weisser A, Menger MD, Kollmar O: Hepatic arterial infusion of temsirolimus inhibits tumor growth of colorectal rat liver metastases even after a growth stimulating procedure like liver resection. J Surg Res 2013;185:587-594.

57 Mahalingam D, Medina EC, Esquivel JA, 2nd, Espitia CM, Smith S, Oberheu K, Swords R, Kelly KR, Mita MM, Mita AC, Carew JS, Giles FJ, Nawrocki ST: Vorinostat enhances the activity of temsirolimus in renal cell carcinoma through suppression of survivin levels. Clin Cancer Res 2010;16:141-153.

58 Gandhi M, Kuzel T, Lacouture M: Eosinophilic rash secondary to temsirolimus. Clin Genitourin Cancer 2009;7:E34-36.

59 Coulter DW, Wilkie MB, Moats-Staats BM: Inhibition of IGF-I receptor signaling in combination with rapamycin or temsirolimus increases MYC-N phosphorylation. Anticancer Res 2009;29:1943-1949.

60 Jiang T, Yu JT, Zhu XC, Tan MS, Wang HF, Cao L, Zhang QQ, Shi JQ, Gao L, Qin H, Zhang YD, Tan L: Temsirolimus promotes autophagic clearance of amyloid-beta and provides protective effects in cellular and animal models of Alzheimer's disease. Pharmacol Res 2014;81:54-63.

61 Fleming GF, Filiaci VL, Marzullo B, Zaino RJ, Davidson SA, Pearl M, Makker V, Burke JJ, 2nd, Zweizig SL, Van Le L, Hanjani P, Downey G, Walker JL, Reyes HD, Leslie KK: Temsirolimus with or without megestrol acetate and tamoxifen for endometrial cancer: a gynecologic oncology group study. Gynecol Oncol 2014;132:585592.

62 Alvarez EA, Brady WE, Walker JL, Rotmensch J, Zhou XC, Kendrick JE, Yamada SD, Schilder JM, Cohn DE, Harrison CR, Moore KN, Aghajanian C: Phase II trial of combination bevacizumab and temsirolimus in the treatment of recurrent or persistent endometrial carcinoma: a Gynecologic Oncology Group study. Gynecol Oncol 2013;129:22-27.

63 Borst O, Schmidt EM, Munzer P, Schonberger T, Towhid ST, Elvers M, Leibrock C, Schmid E, Eylenstein A, Kuhl D, May AE, Gawaz M, Lang F: The serum- and glucocorticoid-inducible kinase 1 (SGK1) influences platelet calcium signaling and function by regulation of Orai1 expression in megakaryocytes. Blood 2012;119:251-261.

64 Gawaz M: Role of platelets in coronary thrombosis and reperfusion of ischemic myocardium. Cardiovasc Res 2004;61:498-511.

65 Pyo JS, Cho WJ: Mean Platelet Volume, Platelet Distribution Width, and Platelet Count in Varicocele: A Systematic Review and Meta-Analysis. Cell Physiol Biochem 2016;38:2239-2246.

-66 Tien AJ, Chueh TH, Hsia CP, Chien CT: Monascus Adlay and Monacolin K Attenuates Arterial Thrombosis in Rats through the Inhibition of ICAM-1 and Oxidative Stress. Kidney Blood Press Res 2016;41:815-827.

67 Velez P, Ocaranza-Sanchez R, Lopez-Otero D, Grigorian-Shamagian L, Rosa I, Guitian E, Garcia-Acuna JM, Gonzalez-Juanatey JR, Garcia A: Alteration of platelet GPVI signaling in ST-elevation myocardial infarction patients demonstrated by a combination of proteomic, biochemical, and functional approaches. Sci Rep 2016;6:39603.

-68 Zlobina KE, Guria GT: Platelet activation risk index as a prognostic thrombosis indicator. Sci Rep 2016;6:30508.

69 Kazama I, Baba A, Endo Y, Toyama H, Ejima Y, Matsubara M, Tachi M: Salicylate inhibits thrombopoiesis in rat megakaryocytes by changing the membrane micro-architecture. Cell Physiol Biochem 2015;35:23712382.

70 Gowert NS, Klier M, Reich M, Reusswig F, Donner L, Keitel V, Haussinger D, Elvers M: Defective Platelet Activation and Bleeding Complications upon Cholestasis in Mice. Cell Physiol Biochem 2017;41:2133-2149.

71 Wang Y, Andrews M, Yang Y, Lang S, Jin JW, Cameron-Vendrig A, Zhu G, Reheman A, Ni H: Platelets in thrombosis and hemostasis: old topic with new mechanisms. Cardiovasc Hematol Disord Drug Targets 2012;12:126-132. 


\section{Cellular Physiology Cell Physiol Biochem 2017;42:1252-1263 \begin{tabular}{l|l|l} 
DOI: 10.1159/000478954 & $\begin{array}{l}\text { O 2017 The Author(s). Published by S. Karger AG, Basel } \\
\text { www.karger.com/cpb }\end{array}$ \\
\cline { 2 - 3 }
\end{tabular} \\ Cao et al.: Temsirolimus Sensitive Platelet Function}

72 Bergmeier W, Stefanini L: Novel molecules in calcium signaling in platelets. J Thromb Haemost 2009;7 Suppl 1:187-190.

73 Varga-Szabo D, Braun A, Nieswandt B: Calcium signaling in platelets. J Thromb Haemost 2009;7:10571066.

74 Xia W, Li Y, Wang B, Chen J, Wang X, Sun Q, Sun F, Li Z, Zhao Z: Enhanced Store-Operated Calcium Entry in Platelets is Associated with Peripheral Artery Disease in Type 2 Diabetes. Cell Physiol Biochem 2015;37:1945-1955.

75 Liu G, Liu G, Chen H, Borst O, Gawaz M, Vortkamp A, Schreiber R, Kunzelmann K, Lang F: Involvement of Ca2+ Activated Cl- Channel Ano6 in Platelet Activation and Apoptosis. Cell Physiol Biochem 2015;37:19341944.

76 Honisch S, Gu S, Vom Hagen JM, Alkahtani S, Al Kahtane AA, Tsapara A, Hermann A, Storch A, Schols L, Lang F, Stournaras C: Chorein Sensitive Arrangement of Cytoskeletal Architecture. Cell Physiol Biochem 2015;37:399-408.

77 Liu G, Liu G, Alzoubi K, Chatterjee M, Walker B, Munzer P, Luo D, Umbach AT, Elvira B, Chen H, Voelkl J, Foller M, Mak TW, Borst O, Gawaz M, Lang F: CD44 sensitivity of platelet activation, membrane scrambling and adhesion under high arterial shear rates. Thromb Haemost 2015;115:

78 Liu G, Cao H, Liu G, Heinzmann D, Chen H, Umbach AT, Gawaz M, Lang F: Effect of Lysosomotropic Polyamineoxidase Inhibitor MDL-72527 on Platelet Activation. Cell Physiol Biochem 2016;38:1695-1702.

79 Liu G, Liu G, Chatterjee M, Umbach AT, Chen H, Gawaz M, Lang F: Influence of gamma-Secretase Inhibitor 24-Diamino-5-Phenylthiazole DAPT on Platelet Activation. Cell Physiol Biochem 2016;38:726-736.

-80 Lang E, Gatidis S, Freise NF, Bock H, Kubitz R, Lauermann C, Orth HM, Klindt C, Schuier M, Keitel V, Reich M, Liu G, Schmidt S, Xu HC, Qadri SM, Herebian D, Pandyra AA, Mayatepek E, Gulbins E, Lang F, Haussinger D, Lang KS, Foller M, Lang PA: Conjugated bilirubin triggers anemia by inducing erythrocyte death. Hepatology 2015;61:275-284.

-81 Lhermusier T, Chap H, Payrastre B: Platelet membrane phospholipid asymmetry: from the characterization of a scramblase activity to the identification of an essential protein mutated in Scott syndrome. J Thromb Haemost 2011;9:1883-1891.

-82 Badlou BA, Wu YP, Smid WM, Akkerman JW: Platelet binding and phagocytosis by macrophages. Transfusion 2006;46:1432-1443. 